\title{
Conceptual metaphors in the naming convention of the United States Armed Forces
}

Karol Plichta | Wydział Filologiczny, Uniwersytet Gdański

\section{Metafory pojęciowe w konwencji nazewnictwa Sił Zbrojnych Stanów Zjednoczonych}

\section{Streszczenie}

Słowa kluczowe:

metafora,

metafora

konceptualna,

nazwy własne,

żargon wojskowy

Poniższy artykuł jest poświęcony analizie wybranych nazw zwyczajowych statków powietrznych i wyposażenia Sił Zbrojnych Stanów Zjednoczonych. Opracowanie bierze pod uwagę ściśle metaforyczny charakter nazewnictwa, a także bazuje głównie na teorii metafory pojęciowej. W toku analizy wykazano, że powstanie poszczególnych określeń dla rozważanych desygnatów jest umotywowane sferą empiryczną użytkowników języka i charakterem służby w siłach zbrojnych. Rezultatem analizy jest identyfikacja wielu metafor pojęciowych. Niniejszy artykuł jest w dużej mierze oparty na pracy licencjackiej autora napisanej pod kierunkiem dr Joanny Redzimskiej z Uniwersytetu Gdańskiego.

\section{Abstract}

This paper is concerned with a linguistic analysis of selected popular names of the United States Armed Forces airplanes and military equipment. The study takes into consideration the strictly metaphorical character of the naming conventions and makes primary use of the conceptual metaphor theory. In the analysis, it is claimed that the emergence of metaphorical names for military vehicles and equipment is motivated by the experiential reality of language users and the character of armed service. Thus a number of conceptual metaphors are identified. This paper is essentially an abridged version of the author's Bachelor's thesis supervised by dr Joanna Redzimska at the University of Gdańsk. 


\section{Military naming convention of the United States Armed Forces}

It is common practice for militaries around the world to assign to vehicles and equipment, such as planes or missiles designations which can be used for their swift and exact identification, and the United Stated Armed Forces are no exception to this tendency. First of all, the role of the naming system, as developed by the United States Department of Defense, is to give a particular vehicle a designation which incorporates all the necessary information regarding its type, basic role, design number, configuration, etc. Also, apart from a short, alphanumeric symbol, whose nature has been briefly described above, most of the vehicles carry a separate, common name which usually consists of a single word as in, e.g., FA-18 Hornet. Most, if not all, such names are apparently of metaphorical nature, and allude to a number of concepts, such as animals, historical figures, and even phenomena arousing strong religious connotations. It is not surprising that the nature of the aforementioned concepts correlates with the character of armed service, as they contribute to the archetypical model of a warrior common in the Occidental culture since, at least, the times of Homer's Illiad. Michał Golubiewski (Golubiewski 2012: 87-91), after Steve Thorne (Thorne 2006: 2427), lists several common names of military vessels and vehicles used by the British and the American armed forces, and explains that such names are either indicative of masculine stereotypes, or relate to folklore, religion, and myths. Common names for military vehicles of identical provenience are subject of the subsequent analysis.

\section{The conceptual metaphor theory and methodology}

The research conducted by Mark Johnson and George Lakoff (1980) marked the emergence of a new current in the development of linguistic studies. Overall innovative, yet fundamentally reminiscent of the theories put forward by Max Black (Black 1954; 1979), Metaphors We Live By (Johnson, Lakoff 1980) has become an indispensable ally for every researcher representing the cognitive approach to metaphor in linguistics. Lakoff and Johnson propose that metaphor is not merely a function of language but, more importantly, of thought. The central point of the conceptual metaphor theory is the hypothesis that metaphorical thinking is one of the more significant instruments of human cognition. According to the aforementioned scholars, conceptual metaphor essentially consists in understanding one phenomenon in terms of another. The character of a metaphorical projection is uni-directional and involves abstract and concrete domains of experience, where the concrete domain is usually responsible for arranging the structure of a less readily comprehensible concept. As a proof, the theory states that natural language is the source of a wide range of metaphorical expressions which have permanently entered everyday communication and thus indicate how the immediate reality is conceptualised by ordinary speakers. The most notable example is the metaphor of life understood in terms of a journey, where, for example, everyday issues are conceptualised in terms of physical 
obstacles in one's path, hence the expressions such as "come across problems", or "surmount difficulties".

In order to facilitate the understanding of the theory it is helpful to briefly refer to the aforementioned "domains of experience" which take part in metaphorical projections. Although mentioned in the scholars' fundamental work (Johnson, Lakoff 1980: 69), cognitive models received more thorough attention several years later. Lakoff in his Women, Fire and Dangerous Things (Lakoff 1987) introduces the concept of Idealised Cognitive Models which are basically vast repositories of experiential knowledge. Such models constitute all the facts and experiences associated with given phenomena, and are the main source of information for establishing metaphorical concepts. The subsequent argument makes extensive use of the notion of cognitive models in explaining the metaphors involved in the analysed military designations.

For the purpose of the present work it is necessary to take into consideration the universal character of military service and all the resulting implications. In other words, the analysis takes into account not only the ethos of the members of armed services, but also, the features of vehicles and missiles in question. The main point of this article is to present that the metaphors involved in the naming convention of the United States Military may be considered in terms of the conceptual metaphor theory. The purpose of the following analysis is to establish a general set of conceptual metaphors governing the emergence of such a naming convention, and explain the conceptual motivations behind the expressions. The analysis consists of two main parts and each of them explores a different aspect of the metaphorical transfers involved.

\section{Personifications and a case of animalisation}

This class of designations has been organised on the basis of their personifying character, since they imply qualities usually associated with living creatures and their behaviour. Furthermore, it is necessary to introduce a further division which is based on the aspect of perceived 'violence' expressed by particular designations. This group is divided into the designations which refer to activities involving violence, and the ones which imply the purpose of a given aircraft without activating that notion.

The two designations ascribed to the 'violent' subcategory are: A3-A Skywarrior and $R Q-1 A$ Predator. Since each of these designations rely on straightforward personifications, it is appropriate to suggest that the highest order conceptual metaphor at work is AN OBJECT IS A LIVING CREATURE. In this case, it is possible to derive a series of more specific metaphors which are: AN AIRCRAFT IS A WARRIOR and AN AIRCRAFT IS A PREDATOR.

The A3-A Skywarrior designation is attributed to the United States Navy aircraft whose primary role, according to the Department of Defense official Model Designation of Military Aerospace Vehicles document, is to attack, which means it is employed 
in a strictly offensive manner. From now on, the aforementioned document will be referred to as "the (official) Department of Defense document". In order to recognize and understand the metaphor involved in the designation, it is necessary to gain access to the cognitive models AIRCRAFT and WARRIOR, which are further interrelated by the context of military. In its simplest form the cognitive model AIRCRAFT evokes an image of an aerial vehicle capable of quick and easy transition from point $A$ to point $B$. This image is sufficient to account for the prefix sky being used in the designation, since the environment in which airplanes operate is the space high above the surface of earth, usually inaccessible by any other means. Furthermore, a language user has to retrieve the information stored in the long term memory regarding the cognitive models of violent behaviour and armed forces. The word warrior evokes the image of a human being engaged in destructive and harmful activities. Warriors are usually assembled into armies which become formal groups adopting a particular set of beliefs and conduct. This is where the context of military appears, and it is by its means that the network of associations between the vehicle and its reference becomes established.

When considering the vehicle and its designation in an objective fashion, there is no reason for assuming their mutual relation, since the aircraft in question is merely a machine capable of fast transition equipped with devices used to exert physical force over other humans, and not a living creature capable of conscious, violent action as its name suggests. However, a language user will not deem the designation unreasonable, but instead will subconsciously comprehend the metaphorical overtones hidden in it, which is due to human cognitive abilities, that of metaphorical thinking among them.

Since humans are predators of some sort it does not seem wholly unfitting to include the following common name into the present category, yet, due to the debatable nature of the term, it has been decided to consider this example as a case of animalisation. RQ-1A Predator is an unmanned aircraft used chiefly for reconnaissance. The Department of Defense document describes the RQ-1A as: "Medium-altitude endurance UAV (unmanned aerial vehicle) capable of carrying a 450 pound payload". Since the purpose of reconnoitring is to secretly gather information about the enemy, it does not presuppose attacking, which could disclose the whereabouts of the intelligence collecting element, thus compromising the mission. In the light of this argument, the question of the violent aspect of this designation as opposed to the actual employment of the vehicle appears troublesome to answer. This observation leads to the assumption that what is suggested by this designation is the more complex nature of a predatory act, which does not only focus on the violent action, but also on the preliminary stage of searching for and approaching the prey. It is significant that, a few years after its introduction into service, the aircraft was modified to carry lethal ordnance, therefore it is able both to seek and destroy a target. 
Once more, in order to identify the metaphor a language user has to access the cognitive models AIRCRAFT and, possibly, PREYING. The choice of the latter cognitive model is dictated by simple convenience as it comprises many smaller acts which make up the whole concept. A prototypical act of preying usually entails a number of activities such as looking for the victim; identifying and observing; following and approaching; seizing and killing, etc. Such activities are similar to what is done in case of a reconnaissance mission with the optional element of lethal engagement. In light of the above arguments, it is suggested that the metaphor present in the designation is AN AIRCRAFT IS A PREDATOR.

\section{Generalizations of non-violent qualities of aircraft}

The designations ascribed to this subcategory are: E-3A Sentry and MQM-107A Streaker. Apart from being of strictly personifying character, both of the designations imply a more specific purpose for which the aircraft are employed, the former example being more straightforward in this respect than the latter. The word sentry belongs inherently in the military discourse, thus a regular language user may infer a more or less logical reason for its use as a designation. On the other hand, the presence of the word streaker appears troublesome to explain since it is not associated with any of the major concepts involved in the domain of military service, but when learning of the aircraft's actual role, the reason behind such naming convention becomes more comprehensible.

First of all, the name E-3A Sentry will be "examined. According to the official Department of Defense document, the alphanumeric part of the designation defines the aircraft as "Special Electronic Installation". Furthermore, the document describes the aircraft in the following words: "Boeing model 707-300 series with large, fuselagemounted, rotating dish radome. Used in command, control surveillance, weapons control, communications relay, self-defense, and threat evaluation/warning". What can be, thus, concluded, is that the aircraft serves an important role in gathering and evaluating intelligence about the situation on the battlefield by means of sophisticated electronic equipment.

Being unaware of the actual purpose of the aircraft, an ordinary language user may still successfully comprehend the metaphor present in the designation, and this is due to the context of military in which the cognitive models of AIRCRAFT and SENTRY appear. However, given the more specific knowledge of the aircraft, the conceptual background behind establishing such a parallel between the above models becomes even more explicable.

First of all, it is important to acknowledge the most general metaphor involved in the designation, which is AN INANIMATE OBJECT IS A PERSON. This metaphor leads to a number of other metaphorical associations which are derived from the physical properties of the aircraft and the mental or receptive capabilities of humans. One of 
these metaphors may be phrased as ELECTRONICS ARE SENSES. By means of various electronic devices onboard the aircraft, operators are able to assess the conditions and circumstances present on the battlefield. The variety of radars, sensors and computers become the "eyes and ears" of the aircraft, and, consequently, of the men controlling them. A radar can "track" the movement of a given vehicle, but, as a matter of fact, it does not do more than sending and receiving radio waves which are then interpreted by another score of electronic equipment to be finally read by the operator of the machine. The electronics of the aircraft are, thus, conceptualised as the actual eyes and ears of the metaphorical sentry. Therefore, another lower-order metaphor at work in this case is OPERATING IS OBSERVING. The concept represented by the model OPERATING, which has been used as a summarising term similarly as PREYING in the previously discussed example, is the aircraft being airborne and its crew employing its equipment to recognize the situation on the battlefield. The aircraft "observes" the front in a similar manner as a sentry would do it with the aid of sight or hearing. Thus, the above seems sufficient to acknowledge the following metaphor AN AIRCRAFT IS A SENTRY.

At the first sight, the MQM-107A Streaker designation may not summon any immediate associations between what it means literally and a possible military vehicle it may describe. However, having learned of the purpose of the aircraft, which is a target drone, the relationship between the vehicle and its name appears less unfounded.

The Department of Defense document describes the MQM-107A Streaker as follows: "Remotely controlled, variable-speed, recoverable, gunnery target drone. Ground launch with JATO assist". The most important phrase of this description is "gunnery target drone", which means that this aircraft is employed as a target for live fire exercise. Such aircraft are unarmed and controlled remotely, and are used for the purpose of training future pilots in aerial combat or testing anti-aircraft weaponry.

Based on an obvious personification, the metaphor which may be the key to understanding the motivations behind the designation is AN AIRCRAFT IS A PERSON. Empirically, there can be little possible association between a person running naked in public and a jet powered aircraft. However, it is possible to search for a metaphorical parallel between the concepts of being unarmed and being nude. The aircraft is "stripped" of any weapons the same way as a streaker is devoid of clothing, thus the former is vulnerable in battle, and a naked person is susceptible to, for example, adverse weather. Another fact which may be metaphorically associated with the concept of streaking is the aircraft's distinctive bright colour. Target drones are painted bright colours in order to be easily visible for salvage crews, while streakers act on the premises of receiving attention. Therefore, another lower-order metaphor involved is NOTICEABILITY IS NUDITY, as the aircraft's bright colour is metaphorically likened to a person's naked body. Based on the above-specified characteristics, the metaphor AN AIRCRAFT IS A STREAKER becomes viable. 


\section{Designations relating to groups of people or particular figures}

Another class of designations is characterised by the reference to a defined group of people or a specific individual. Even though this group is based on the concept of personification, there is a difference in the degree of definiteness. In other words, designations containing such words as skywarrior or predator are less precise when compared to A-7A Corsair II and C-130A Hercules, which are the subject to be discussed in this subsection. These designations still imply the combat purpose or the function of the aircraft, and are based on underlying metaphorical concepts.

The A-7A Corsair II designation does not seem to stir up much thought-provoking controversy, since it is not uncommon for military equipment to be named after people or objects generally associated with violence or warlike behaviour. The official Department of Defense document describes A-7A Corsair II as: "Light, single-place, carrier-based, attack aircraft. Used primarily for tactical strike, close air support, and interdiction missions". Also, another crucial information provided by the document is that the principal user of the aircraft is the United States Navy, which means that the aircraft operates mainly in maritime environment. Furthermore, the "attack aircraft" phrase, as well as the alphanumeric part of the designation, signify the offensive potential of the aircraft.

As in every case of personification, the metaphor AN OBJECT IS A PERSON appears as the most general, and is the foremost source for other metaphorical concepts which seem to have prompted the lexical choice for this particular designation. To understand the metaphorical link between the aircraft and the concept represented by its popular name a language user will correlate the information stored in the cognitive models of CORSAIR and AIRCRAFT. The elementary parallel between them is that of the environment in which a corsair and the aircraft in question operate. A7-A is essentially a volitant vehicle, but the sole fact of it being mostly deployed from ships exerts an influence on how the type of environment in which it is actually destined to serve is perceived. Thus, one of the most prominent metaphorical concepts involved in this designation is AIR IS SEA, where air becomes the sea at which the metaphorical corsair operates. Another important aspect, apart from the environment in which a corsair or an A-7A operate, is the range of activities they are involved in. A corsair is an outlaw who robs ships with the use of violence, while an aircraft is simply a volitant vehicle. However, the aspect of violence of the latter is manifested in the very fact that it was designed to be used in battle. This creates grounds for the AN AIRCRAFT IS A CORSAIR conceptual metaphor to emerge.

Another designation considered in this section alludes to the mythical hero who distinguished himself with extraordinary feats of strength and courage, namely to Hercules. Although a mythical figure, Hercules has been portrayed as a human, therefore he bears much resemblance to an ordinary man albeit equipped with superhuman 
abilities. In other words, the figure of Hercules is based on the image of a human being, thus it is possible to speak of personification in this case.

The official Department of Defense document describes the C-130A Hercules aircraft in the following way: "High wing, medium range transport (4 crew, 92 troops, or 70 litters)". Also, the letter " $\mathrm{C}$ " of the alphanumeric part of the designation indicates the aircraft's primary mission as "transport". The above specifications lead to the conclusion that the main utility function of the aircraft is transporting a variety of cargo.

In order to comprehend the relationship between the designation and the object it relates to, a language user must refer to the cognitive models AIRCRAFT and HERCULES. The highest order AN OBJECT IS A PERSON metaphor is still relevant in this case, and is the source of at least one, more specific metaphorical projection. Given the aircraft's transporting capabilities and the superhuman strength of the mythical hero, it is suggested that one of the most important metaphors underlying this designation is CARRYING CAPACITY IS PHYSICAL STRENGTH. The cognitive model CARRYING CAPACITY is connected with the aircraft's ability to carry and deliver heavy payload over long distances, while PHYSICAL STRENGTH is involved in the outstanding physical abilities of Hercules. This, in turn, allows to acknowledge the following metaphor A LARGE AIRCRAFT IS HERCULES.

\section{Designations relating to supernatural phenomena or to physical objects}

The last class of designations to be discussed has been organised according to their non-personifying character. The names of the first two objects are related to violent or non-violent phenomena, while the other two designations refer to inanimate entities. Again, what is hidden behind the names of the equipment is the implied purpose or a distinguishable feature of the aircraft or the weapon. A novel feature in this group of designations is the appearance of names denoting lethal ordnance AGM-114A Hellfire and AGM-84A Harpoon. What is interesting to note is the ideological charge of the former example, and the apparent religious connotation allows for inferring a number of assumptions of how the missile and the war itself can be conceptualised.

Since AGM-114A Hellfire refers to a phenomenon from religious beliefs, it is necessary to acknowledge all the consequences resulting from this fact. Not only may the name allude to the devastating effects of employing this type of munitions, but it also can be associated with more ideological aspects such as the moral position and motivations of the operator and the target.

The official Department of Defense document describes AGM-114A Hellfire in the following words: "Helicopter-launched anti-armor missile equipped with terminal-homing seeker and shaped-charge warhead". Since the word hellfire is a compound, 
the initial position of the stem hell indicates its attributive role with regard to the latter constituent. The highest-order metaphor which structures the network of correlations between the cognitive models MISSILE and HELLFIRE may be represented as AN OBJECT IS A SUPERNATURAL PHENOMENON. The recognition of this metaphor allows for creating a series of correspondences between the lower-order concepts inherent in each of the aforementioned cognitive models.

The effects of the missile's blast comprise a high-pressure shock wave and emission of excessive heat, which are accompanied by shrapnel scattering. These elements are responsible for the destructive potential of the conventional munitions of today's military, as well as for the harmful effects of using the missile in question. On the other hand, hellfire evokes the image of flames of Hell, which are believed to be the punishment for the wicked and cause of their eternal suffering. Thus, it is suggested that the conceptual link between the effects of the explosion of the missile and the supernatural phenomenon is established on their pernicious effects on human body. While hellfire is the symbol of suffering in afterlife, the actual effects of an explosion may be comparable, even though they occur in the domain of the physical world. Having considered the above, the BLAST IS HELL metaphor may be derived, where BLAST refers to the physical effects of the explosion including heat and flames, and HELL relates to the eternal suffering caused by the menacing flames of the Inferno. Therefore, it can be said that EXPLOSION IS HELLFIRE metaphor is present in the considered designation.

Another designation alluding to a supernatural, albeit non-violent, phenomenon is B2-A Spirit. The Department of Defense document describes B-2A Spirit in the following words: "Advanced technology bomber that incorporates stealth Technology. Has long range and large payload". This rather concise description reveals an important characteristic which may have been the main reason for adopting the word spirit for the name of this bomber. The term "stealth Technology" encompasses all the technical properties that allow an aircraft to reduce its radar signature, in other words, it is less prone to detection for radars. This feature enables the aircraft to stay undetected until it is too late for any defensive manoeuvres to be undertaken, thus provides the advantage of a surprise attack.

In order to comprehend the metaphorical character of the designation a language user has to access the cognitive models of AIRCRAFT and SPIRIT. The general idea of a spirit can evoke images of an disembodied, translucent apparition, often of humanlike characteristics as often visualised in films or characterised in literary descriptions. The aspect of immateriality or partial invisibility of a spectre may be compared to the special features of the aircraft in question. Although it is impossible for the bomber to become literally invisible or to lose its physical form, the fact that it is less susceptible to radar detection may be correlated with the supernatural character of a spirit. The aircraft becomes metaphorically less "visible" for the tracking equipment the same way as an imaginary phantom is elusive to the human eye. Therefore, what seems to 
be involved in the name of the aircraft is the metaphorical mapping IMMATERIALITY IS INVISIBILITY, where IMMATERIALITY relates to the aircraft's assumed ability to dematerialise, and INVISIBILITY is a result of the impossibility to observe an immaterial entity. The above arguments appear sufficient to recognize the conceptual background for the AN AIRCRAFT IS A SPIRIT metaphor.

The case of the EC-135C Looking Glass designation is different from the ones that have already been discussed, since the name does not allude to a living organism or an abstract phenomenon but to a concrete material object. EC-135C Looking Glass is described in the official Department of Defense document as: "Improved C-135B with different engines and electronics for airborne command post and communication relay capability. Formerly KC-135B". The above description characterises the aircraft as a modified transport plane furnished with electronics and communication equipment, which is also appropriately indicated by the alphanumeric part of the designation. However, the most important phrase of the description is "airborne command post". The aircraft was meant to serve the same function as the command posts on the ground just in case they were destroyed by nuclear strikes, so that the United States military could retain full operational capabilities by maintaining similar type of headquarters in the air. Also, the crew onboard the aircraft was able to give the same orders as their counterparts on the ground.

Having considered the aircraft's function, it is possible to draw some conclusions about the conceptual motivations which constitute the background for the designation. Although the aircraft itself, unless its fuselage is shiny, cannot reflect anything as a looking glass does, it duplicates the strategic relevance of the personnel it is supposed to replace in case of their demise. In other words, the aircraft and its crew "mirror" the responsibilities and powers of a command post located on the ground, the same way as a mirror reflects the exact image of what is in front of it. Given the above, the following metaphorical concept can be recognized as the one involved in the term: REPLICATING IS REFLECTING, where REPLICATING concerns the aircraft's military function of a duplicate aerial command post, and REFLECTING refers to the physical properties of a mirror. Consequently, the above-specified mapping provides some motivation for the designation of the aircraft in question.

The last designation to be considered is AGM-84A Harpoon. In this case, a missile is named after an object which serves as a tool for hunting fish by penetrating their flesh. Seemingly, the capability of inflicting injuries is the only link between the two objects which contributes to establishing their metaphorical analogy. Nevertheless, a harpoon and the missile in question have in common more than what can be inferred from the designation at first sight.

The Department of Defense official document describes AGM-84A Harpoon in the following words: "Air-to-surface guided missile designed to destroy ship targets". Regardless of its launch environment, which is indicated by the first capital letter of the 
alphanumeric part of the designation, the missile was designed to engage a variety of naval targets, excluding submarines. Thus, the most prominent parallel between a harpoon and the missile is the maritime environment in which both were designed to be used.

In order to comprehend the metaphorical associations between the missile and its designation it is necessary to refer to the cognitive models MISSILE and HARPOON. The number of analogies that are established between the two concepts is dependent on the amount of information which is available to a given language user. Even without the specific knowledge of the missile's purpose it is still possible to arrive at conclusions regarding the motivations of the lexical choice made in the case of this designation. Lacking specialised knowledge, it can be still deduced that both the missile and a harpoon are types of weapons intended to cause immediate physical damage. Also, the missile and a harpoon are both ranged weapons, meaning that they are controlled from a distance. The fact that both objects are used in maritime environment in order to inflict damage is crucial for the way of how the metaphorical link between the two concepts is established. The above arguments are sufficient to recognize the A MISSILE IS A HARPOON metaphorical background.

\section{Conclusions}

The main point of this research has not been to state the obvious i.e., that the analysed designations are metaphoric in nature, but to provide more evidence that the conceptual metaphor theory is a viable hypothesis, and may well be used in analysing a vast range of language. Moreover, the study shows the ubiquity of metaphor, and, consequently, metaphorical thinking, since even military equipment may be conceptualised in such manner. Another interesting fact is that some of the analysed examples seem to avoid the traditional conceptual interpretation since in a few cases it can be noted that the source domain is not concrete at all, and the target domain is not abstract either. Hellfire or spirit can be hardly called phenomena whose nature is grounded in some basic domains of experience, yet they both act as source domains in the relevant metaphorical projections. The reason for this anomaly may be the fact that military names are just a part of the larger social construct of military service whose exact nature is warranted by a number of factors. One of these factors is the propagandistic effect which the names exert on the public reception of warfare and the equipment involved. A harpoon is often used to kill fish and provide food, thus military action which utilises equipment bearing a similar name may be conceptualised in terms of hunting; war being a means of one's own survival. The idea of preventive action or acting in self-defence is often exploited by politicians in order to justify waging war. Also, in the case of the Hellfire missile, the implications are that the target is condemned to damnation because of its low moral standing, and the operator is, in turn, responsible for administering justice and giving out punishment to the 
doomed. Such a way of understanding the discussed weapon may prove psychologically beneficial to the person who is in charge of it making its employment less emotionally burdensome. However, as it appears, the most important fact is that cognitive studies like this one may help explore and understand the areas of language influenced by metaphorical thinking.

\section{Bibliography}

Black M., 1954, Metaphor, "Proceedings of the Aristotelian Society", New Series, Vol. 55 (1954-1955), New Jersey: Blackwell Publishing.

Black M., 1979, More about Metaphor. In Ortony A., ed., Metaphor \& Thought, Cambridge: Cambridge University Press.

Golubiewski M., 2012, Angielszczyzna wojskowa, Gdańsk: Wydawnictwo Uniwersytetu Gdańskiego. Lakoff G., Johnson M., 1980, Metaphors We Live By, Chicago: The University of Chicago Press.

Lakoff G., 1987, Women, fire, and dangerous things: what categories reveal about the mind, Chicago: The University of Chicago Press.

Thorne S., 2006, The language of war, London: Routledge.

United States Department of Defense, 2004, Model Designation of Military Aerospace Vehicles, Washington. 